\title{
生体脈波を用いた道路の乗り心地評価 に関する基礎的研究
}

\author{
原田 隆郎1・横山 功一2 \\ 1正会員 茨城大学准教授 工学部都市システム工学科（テ316-8511 日立市中成沢町4-12-1） \\ E-mail: harada@mx.ibaraki.ac.jp \\ 2フェロー 茨城大学名誉教授 工学部都市システム工学科（†316-8511 日立市中成沢町4-12-1） \\ E-mail: yokoyama@mx.ibaraki.ac.jp
}

\begin{abstract}
本研究では, 道路利用者の乗り心地を評価するための走行性指標を提案寸るため, 車両走行中の運転者 および同乗者の生体脈波をセンシングし, 人間の感覚的な観点からの道路の乗り心地を評価する手法を提 案するとともに, 舗装マネジメントにおける乗り心地指標の適用可能性に関する検討を行った. 走行試験 によって計測された生体脈波を用いて, 路面の不陸や段差が道路利用者に与える乗り心地の程度を定量評 価するとともに, 生体脈波のカオス解析によって得られたリアプノフ指数を利用して複数道路の乗り心地 の区別化を行い，舗装マネジメントのための乗り心地評価指標を提案した.
\end{abstract}

Key Words : biological pulse wave, Lyapunov exponent, riding comfort, road asset management

\section{1. はじめに}

現在，安全で快適な交通環境を道路利用者へ提供 することを目標の一つに掲げた道路のアセットマネ ジメントが提唱されている が, 道路の維持管理

（路面調査や補修工事など）の必要性を道路利用者 に受け入れてもらうこと，つまり道路管理に対する アカウンタビリティに関する取り組みは十分に展開 されていない.

一方, 舗装を維持管理するための指標として, 路 面調査データを基本とする道路管理者側の維持管理 指数（Maintenance Control Index，以下 MCIとする） 国際ラフネス指標（International Roughness Index, 以下IRIとする）などがある。また，IRIを利用して 道路利用者の乗り心地を評価する研究 ${ }^{2) ~ 4) ~}$ やIRI と舗 装種別との関係を調査した研究5)もあり，道路利用 者の観点から舗装を評価する動きもある.さらに， ユーザの生体情報の一つである脳波を利用して, 道 路利用者の乗り心地を評価し, マネジメントのため

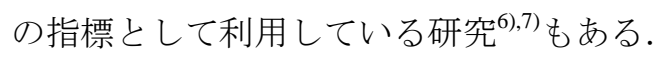

このような現状に鑑み, 本研究では道路利用者の 乗り心地から維持管理における走行性指標を定量化 するため, 外部環境の変化による人体の反応を観察 するのに適していると言われる「脈波」 ${ }^{8), 9)}$ を利用 する. つまり, 車両走行中の運転者や同乗者の生体
情報を脈波センサで計測し，計測された生体脈波を 用いて, 路面の不陸や段差, 平坦性などの走行性指 標（乗り心地）を定量評価する.また，生体脈波に よる乗り心地指標を利用して複数道路の乗り心地の 区別化を行うことで, 舗装マネジメントのための道 路の乗り心地評価に関する適用可能性を検討する.

\section{2. 路面の定量評価と道路の乗り心地評価}

\section{(1) 路面管理指標と乗り心地評価}

前述のように，既存の路面管理指標として代表的 なものは, 維持管理指数 (MCI) や, 国際ラフネス 指標（IRI）などである.

MCIとは，ひび割れ，わだち掘れ，平坦性という 3つの項目の物理的路面性状から路面の健全性を総 合的に評価したものである ${ }^{10)}$.ひび割れは路面に生 じたひび割れの度合いを測定したものであり，わだ ち掘れ量は舗装路面の摩耗, 路盤の沈下, アスファ ルト混合物の流動等によって, 車輪の走行位置に発 生するわだち掘れ量を測定したものである。平坦性 とは，車両の走行時における乗り心地に影響する道 路縦断方向の凹凹の度合いを測定したもので，プロ フィロメータなどで計測される。これらの物理的路 面性状をもとにMCIが算出される.MCIの特徵とし 
ては，わだち掘れの寄与が極めて大きく，逆に乗り 心地に影響する平坦性の寄与は低いことである。 MCIは管理者の着目点である路面の物理的な劣化損 傷を反映した指標であり，このMCIに加えて道路利 用者の乗り心地を評価することが課題である.

IRI は，1986 年に世界銀行が発案したものである。 高速道路などの高い平担性が要求される超長周期の うねりの把握や, 空港の滑走路, または舗装道路と 未舗装道路等，これらを統一した評価で表現できる 指数といわれている。IRIは，任意の測定装置で路 面の縦断プロファイルを測定し, クォーターカーシ ミュレーション（Quarter Car Simulation）によって 算出する。このIRIを用いた道路の乗り心地に関す る検討が行われており，石田ら ${ }^{2)}$ は乗り心地に関す る安心感と平坦性およびIRIの関係について，大野 ら ${ }^{3)}$ はIRIと乗り心地の関係に関する検討について, 諸橋ら ${ }^{4)}$ は道路構造種別とIRIの関係や，IRIの算出方 法に関する検討と乗り心地とIRIの関係について, そして熊田ら ${ }^{5)}$ はIRI と舗装種別の関係について検討 している.

\section{(2) 生体情報を用いた乗り心地評価}

生体情報を用いた舗装の評価として，遠藤ら ${ }^{6), 7)}$ は室内実験によって人が感じる上下方向の振動が, 脳波の変化として現れること確認した，そして，そ の結果を受けて実道路における調査を行い, 利用者 が路面から受ける感覚を判断材料とした舗装の評価 結果を感性によって定量化した。

一方，生体脈波は，簡易に測定が可能で，外部環 境の変化による人体の反応を観察するのに最適な情 報であり, 福祉工学や人間工学などの分野で利用さ れている。生体脈波を用いたドライバの心身状態の

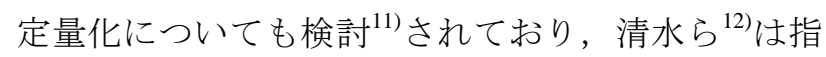
先脈波のカオス動力学に基づいて, ドライバーのワ 一クロードを観測し，その評価方法を確立すること を目的とし，自動車テストコース実験と高速道の実 験を行った。そして, 様々な状況において自動車を 運転しているときに，ドライバーの心身負荷状態， いわゆるメンタルワークロードを評価する方法とし て，指先脈波のカオス動力学の有用性を検討した結 果，テストコースにおける異なる速度の走行実験お よび高速道路の実験の結果, 最大リアプノフ指数は ドライバーのメンタル負担状態の有効な指標である ことを明らかにしている。

本研究では，この生体脈波を道路利用者が車両走 行中に感じる道路の乗り心地を評価するための情報 として利用することを考える。

\section{3. 生体脈波とその特徵量の抽出方法}

\section{(1) 生体脈波とその測定原理}

生体脈波とは，身体組織のある部分への血液の流 入によって生じる容積変化を体表面から波形として とらえたものをいい，血管運動反応をとらえる．生 体脈波は，脳波等に比べて容易に測定を行うことが でき，末梢血管循環動態や自律神経機能と関係する。 計測された脈波からは，単純に心拍数を数えるだけ でなく，波形を微分することや周波数解析をするこ とにより，多くの生体情報を得ることができると考 えられている.

脈波測定は，図-1に示すように指先や耳朵などの 生体組織へ近赤外領域の光を照射し，その反射ある いは透過光を検出するもので, ヘモグロビンの近赤 外光の吸光度を利用して血液の脈動を電気的に測定 するものである。つまり，へモグロビンの量の変化 を電圧值で捉え，A/D変換回路により電圧值を数值 化してPCに表示する. 脈波は横軸に時間, 縦軸にへ モグロビンの量の変化を電圧值で捉えた值で表現さ れる。

\section{(2) カオス解析による脈波の特徵量の抽出方法}

脈波波形はカオス性を有することから，その特徽 量の抽出方法としては一般にカオス解析が用いられ る ${ }^{13)}$. カオス解析では, まずTakensの埋め込み定理 を用いて脈波波形から時間遅れ座標にアトラクタを 構成する。生体情報が不安定な場合, アトラクタの 軌道は複雑になり乱れる。このアトラクタの軌道の 複雑さを表す指標がリアプノフ指数である. 本研究 では,このリアプノフ指数を脈波の特徵量を示す指 標として利用する.

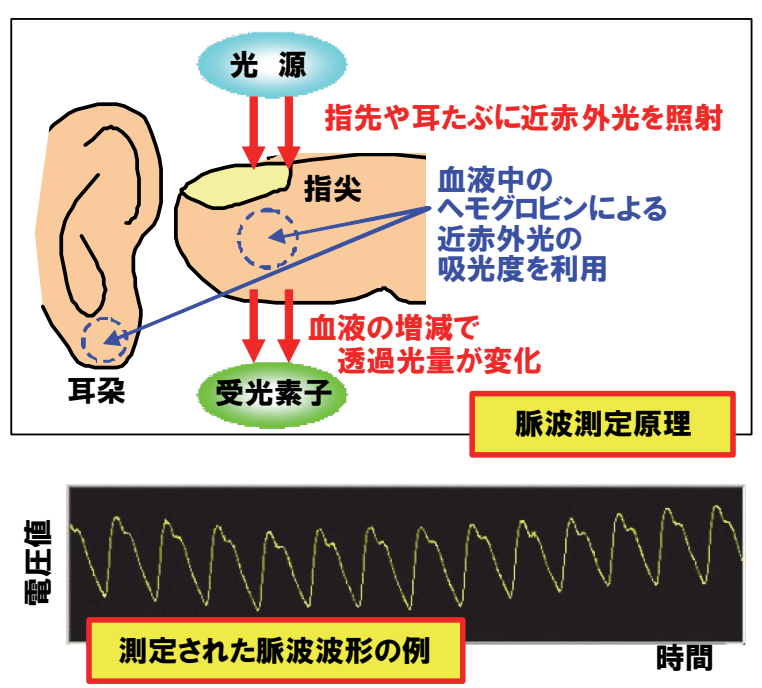

図-1 脈波測定の原理と計測脈波の例 
リアプノフ指数 $\lambda(f)$ は式(1)で計算され, 力学系 $x_{i+1}=f\left(x_{i}\right)$ について, 近接した2点から出発した $2 つ の ~$ 軌道がどのくらいの時に離れていくかを測る尺度と して定義される ${ }^{14)}$.

$$
\lambda(f)=\lim _{N \rightarrow \infty} \frac{1}{N} \sum_{i=0}^{N-1} \log \left|f^{\prime}\left(x_{i}\right)\right|
$$

ここで， $f^{\prime}\left(x_{i}\right)$ は写像拡大率，Nはサンプリングデー 夕数である. カオス解析としてのリアプノフ指数と は, 写像拡大率の対数であり, アトラクタの軌道が どのくらい複雑かを表す指標である。例として，ア トラクタが全く同じ軌道を描く場合にはリアプノフ 指数は 0 となり，軌道が複雑になるほど，リアプノ フ指数の值は大きくなる. リアプノフ指数が大きい ということは，何らかの外界の変化に対して，脈波 が変化しているということを示している。

\section{(3) 本研究における乗り心地指標の定義}

道路の乗り心地に影響を与える要因を考えると， 一般的には道路線形や構造, 舖装路面の段差や凹凸 などの道路側の影響が大きいと考えられる。本研究 では，この道路側の影響を道路利用者の視点から評 価し，道路の乗り心地として把握するため，前項で 述べたリアプノフ指数を乗り心地の指標として定義 する，具体的には，道路利用者の脈波を定量化でき るリアプノフ指数を乗り心地の指標と対応づけるこ とで, 車両走行中の道路利用者が感じる道路の乗り 心地を評価することを試みる。つまり，乗り心地が よい場合には脈波が安定しているためリアプノフ指 数は小さい值を示し，逆に乗り心地が悪い場合には 生体情報が不安定となりリアプノフ指数は安定時に 比べ大きな值を示すことになる．リアプノフ指数と 乗り心地を対応づけることによって，それまで安定 していた脈波が道路の乗り心地の悪さによって変化 する様子を捉えることができたり，乗り心地の異な るさまざまな道路に対して，ユーザの脈波による区 別化が行えるようになると考えられる.

しかしながら，生体情報には個人差や時間依存性 があり，脈波から算出されるリアプノフ指数の大小 にもこれらが影響すると考えられている。これらの 生体情報に含まれる個人差や時間依存性を取り除き, 生体情報による評価指標の普遍性を検討している例

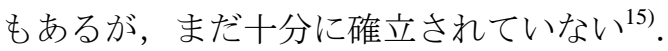

よって，本研究では生体脈波から算出されるリア プノフ指数から個人差や時間依存性を取り除き，乗 り心地の絶対評価を行うのではなく，個人差や時間 依存性の影響を含めた上で乗り心地の違いを相対的
に評価できる指標として, 脈波から算出されるリア プノフ指数を利用する.

\section{4. 走行試験における生体脈波計測と解析方法}

\section{(1) 走行試験の概要}

本研究では，車両走行中の運転手および同乗者の 生体脈波を利用して道路の乗り心地を評価するため, 試験車両（普通乗用車1000cc）による走行試験を実 施した。

車両の走行区間は県内の国道，県道，市町村道お よび有料道路の一部とし，比較的交通量の少なくな る夜間（午後9時頃）に走行試験を実施した。被験 者は運転手および同乗者（後部座席の運転手側に乗 車）とし，運転手および同乗者の生体脈波を計測す る。ここで，夜間の試験ではあるが，被験者の視覚 および聴覚から受ける影響を極力排除するため，同 乗者についてはアイマスクと耳栓を付けて試験を行 った。運転手については，夜間運転に伴う生体への 影響も考えられるが，同一条件で試験を実施するこ とで試験時刻の影響は無視することとした。なお， 各被験者それぞれに1名の試験補助者を同乗させ， 合計4名で試験を実施した（図-2）。なお，本研究 で実施した走行試験の被験者は全員が20歳代の男性

（すべて1年以上の運転経験あり）であり，年齢や 性別の違いによる傾向分析は今後の課題とする.

\section{(2) 脈波計測方法とリアプノフ指数の算出}

本研究では脈波測定機器として, 株式会社CCI社 製の「BACSディテクター」を用いた。測定は付属 の指尖脈波センサ，または耳氺脈波センサのいずれ かを用いる方法があるが，予備実験により両者で計 測される脈波およびリアプノフ指数の差異はほとん どなかったことから，運転手のハンドル操作に影響 を与えない耳架脈波センサを用いた（図-3）。

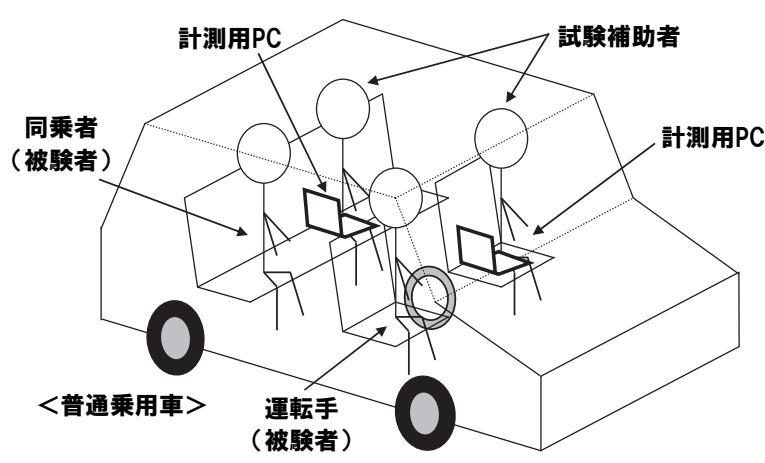

図-2＼cjkstart被験者および試験補助者の配置図 

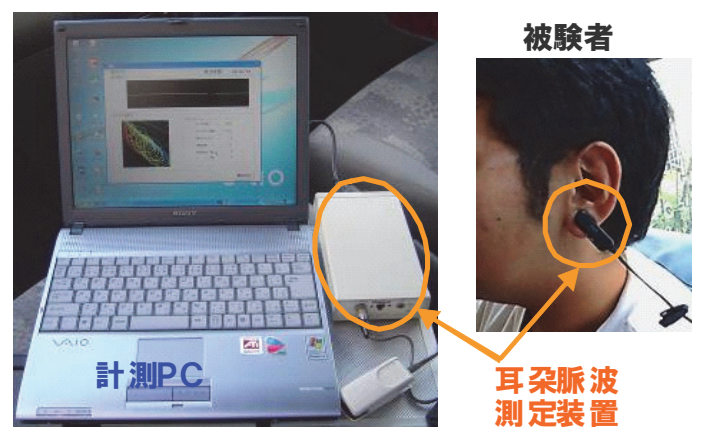

図-3 耳朵脈波測定装置と計測 PC

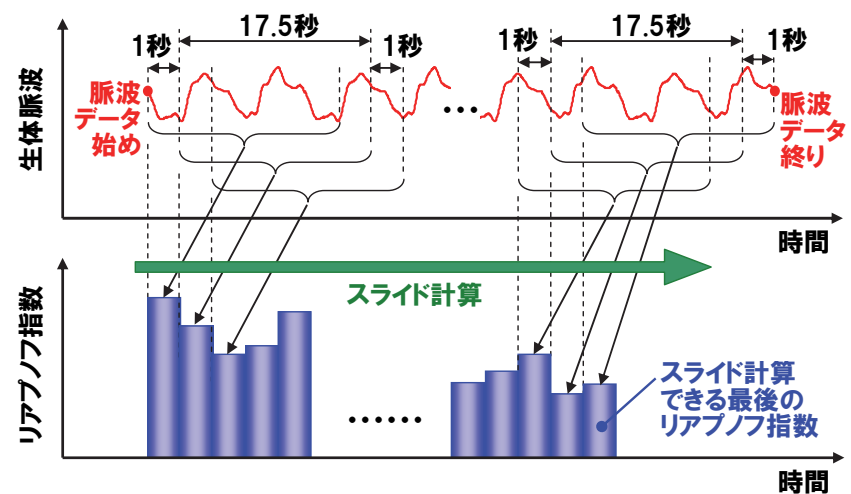

図-4 リアプノフ指数のスライド計算方法
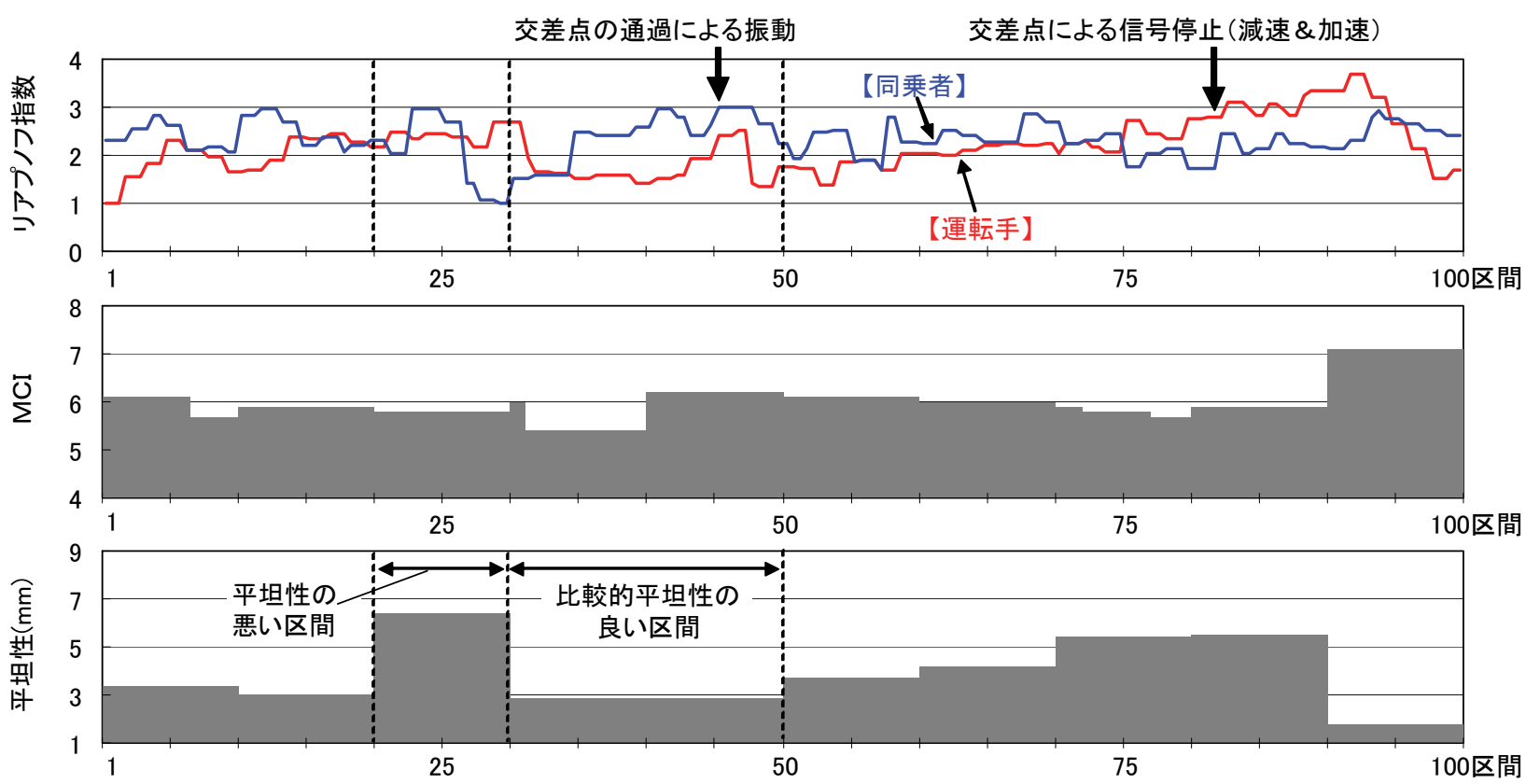

図-5 被験者のリアプノフ指数と路面評価指標（MCIおよび平坦性）の関係

測定された脈波は，同じく株式会社CCI社製の 「リアプノフスライドカルク」を用いてアトラクタ に構成され，そこからリアプノフ指数が式(1)に従っ て計算される。なお，リアプノフ指数は計測された 脈波データからスライド計算されるが，本研究では リアプノフ指数の算出に必要となる脈波計測時間を 参考文献11)および12)において用いられている17.5 秒とした.つまり, 以下で述べる各種実験において は，連続計測された脈波データから17.5秒分を 1 秒 ごとにスライドさせて複数のデータセットとして作 成し，このデータセットごとにリアプノフ指数を算 出する（図-4）。そして，これらのリアプノフ指数 の平均值を，計測した脈波全体の特徴を表すリアプ ノフ指数とした. よって, 以下で用いるリアプノフ 指数は, 特に説明がない限り, 着目している脈波デ ータからスライド計算されたリアプノフ指数の平均 值を表すものとする.

\section{5. 生体脈波と乗り心地の関係分析}

\section{(1) 路面評価指標とリアプノフ指数の関係}

本研究では，まず道路の路面評価指標と生体脈波 の関係を把握するため，一般道を試験走行した場合 の運転手および同乗者の脈波からリアプノフ指数を 算出し, 路面評価指標の中の MCI と平坦性とを比較 した．なお，MCIは路面の状態を総合的に評価する 指標であることから，道路利用者の感覚的な指標で あるリアプノフ指数と相関があるとは予想できない. しかしながら, 道路の乗り心地を表す指標として検 討しているリアプノフ指数の適用範囲を広く確認す るために，まずはMCIとの比較から始めることとし た. また, 平坦性については縦断方向の凹凸量であ り，一般に走行性と関係があると言われていること からリアプノフ指数との比較を行った。

MCI と平坦性の路面性状調査データは, 検討対象 
とした道路区間の管理者から入手したものであり， $20 \mathrm{~m}$ 単位での路面性状調査データを用いている。な お，路面性状調査データの調査年度が異なる道路区 間については，路面性状調査結果を予測式によって 当該時期に換算したデータを入手することで，脈波 の計測時期と整合させた。

試験走行した区間は国道と県道および市道を組み 合わせた延長約 $3 \mathrm{~km}$ であり，試験走行のスタート地 点がゴール地点となるように周回コースと設定した 試験走行区間は信号のない直線区間を含むとともに, 交差点，橋梁（トラス橋）などを通過する。よって, 計測される運転者や同乗者の生体脈波には，信号や 信号停止による車両の減速や加速，交差点の左折， 舗装と橋台背面部との段差（約 $2 \mathrm{~cm} ）$ などが含まれ ている。また，車線数は片側 2 車線の区間と片側1車 線の区間を含むことから，試験走行では2車線区間 の場合，左側車線を走行した。なお，生体脈波の計 測条件としての走行速度は，交通状況や信号停止な どで必ずしも一定に保たれている訳ではないが，各 道路の法定速度から5 10km/h程度遅い速度までの 間で調整し，それを記録した。

図-5に国道区間約 $1 \mathrm{~km}$ で計測された運転者および 同乗者の生体脈波をもとに計算したリアプノフ指数 と同区間のMCIおよび平坦性（mm）を示す。図-5 の横軸は時間を走行地点（1～100区間，1区間は 100m）に対応させて変換したものである。よって, 交差点などでの信号停止時間や走行速度の影響によ って各区間の走行所要時間は異なっており，リアプ ノフ指数の值は各区間の平均值を用いている。また, 各区間とも3回の計測の平均值を表したものである。

図-5より，運転者および同乗者のリアプノフ指数 は必ずしも同じ傾向を示しておらず，さらにリアプ ノフ指数とMCIおよび平坦性の間に顕著な相関は見 られなかった．25区間前後や70区間以降の平坦性の 悪さを運転手および同乗者のリアプノフ指数の変化 から把握できるようにも見えるが，30～50区間のど ちらかと言えば平坦性の良い区間でも同乗者のリア プノフ指数は高くなっており，必ずしもMCIや平坦 性などの路面評価指標にの夕依存するとは言い難い， また，40区間付近では交差点の通過による若干の短 い振動が観察・記録されており，平坦性には現れて こない路面の不陸による凸凹を評価している可能性 が推察される（この検証は次節以降で行う）。また, 88区間付近では走行中の信号停止による減速やその 後の加速においても変化が見られることから，被験 者のリアプノフ指数は，路面評価指標のMCIや平坦 性の影響だけでなく，路面の不陸や段差，さらには 車両の加減速などの走行中の様々な影響（以下では
これをイベントと呼ぶ）を受ける可能性があること が確認できる。

\section{（2）走行中に生じる各種イベントとリアプノフ指数 の関係}

前節において分析した国道区間約 $1 \mathrm{~km} の$ 運転者お よび同乗者のリアプノフ指数から，被験者のリアプ ノフ指数は各種イベント（路面の不陸や段差，車両 の加減速などの走行中の様々な影響）を受ける可能 性があることが確認された。そこで，前節の試験走 行（延長約 $3 \mathrm{~km}$ の全区間）で計測した運転手および 同乗者の生体脈波データから，運転条件や道路条件 に起因した走行中に生じる各種イベントとリアプノ フ指数の関係を把握し，乗り心地に関する影響を分 析した.

ここでは，各イベントが生じたときの前後30秒の 生体脈波データを切り出してリアプノフ指数を計算 した。そして，計算されたリアプノフ指数から，車 両の加減速や右左折，舗装と橋台背面部との段差の 影響を検討し，それぞれの要因と乗り心地との関連 性について考察した.

\section{a) 減速および加速とリアプノフ指数の関係}

まず，測定区間のうち約 $40 \mathrm{~km} / \mathrm{h} て ゙$ 走行中に信号停 止のため減速し，一定時間停止した後，約 $40 \mathrm{~km} / \mathrm{h} ま$ で加速した区間のデータについて分析した．減速し 始めてから停止までに要した時間はおよそ5秒であ

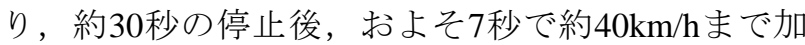
速し，その後は一定速度で走行した。図-6に運転手 と同乗者の脈波から計算されたリアプノフ指数を示 す３回の測定のいずれにおいても，加速時のリア プノフ指数の值が最も大きな值を示しており，次い で減速時のリアプノフ指数の值が大きくなっている このことから，同乗者の脈波は一定速度走行中や停 止時よりも，加速時や減速時に安定しない傾向が見 られた。

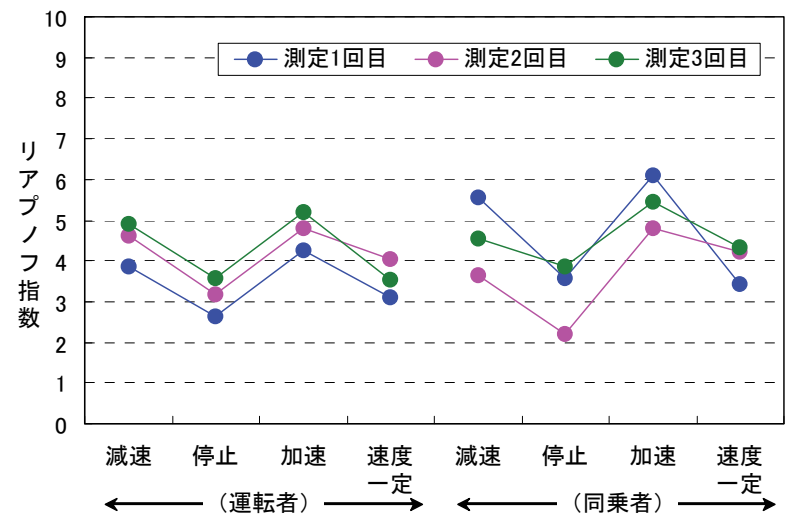

図-6 加減速とリアプノフ指数の関係 


\section{b) 左折とリアプノフ指数の関係}

次に，一定速度（約 $20 \mathrm{~km} / \mathrm{h} ）$ で交差点を左折した 測定区間における運転手と同乗者の脈波を分析した。 交差点を左折する前後の道路はほぼ直線であり, 路 面状態も良い. 図-7に運転手および同乗者の3回分 の測定脈波から計算されたリアプノフ指数を示す.

比較のため直線走行時（速度 $40 \mathrm{~km} / \mathrm{h}$ ) のリアプノフ 指数の平均值もグラフ化した. 3回の測定それぞれ について, 直線走行時と左折時のリアプノフ指数は ほぼ同等と見ることができる，このことから，加減 速の影響と比べ, 低速での左折の影響はあまり大き くないと言える.

\section{c) 段差とリアプノフ指数の関係}

測定区間において, 舖装と橋台背面部との段差

（図-8，段差約2cm）によって走行中に振動を受け る場合を分析した。この区間での車両の走行速度は

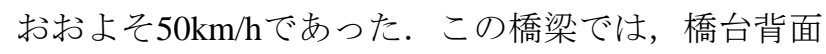
部までの比較的路面状態のよい直線的区間と比べて, 橋梁に入る部分に橋台背面部との段差があるだけで なく, 橋面上も舗装劣化や伸縮装置の段差で振動が 生じており，乗り心地は良いとは言えない。図-9に 運転者と同乗者の脈波から計算されたリアプノフ指 数を示す. 橋梁段差に進入する前後でリアプノフ指 数の平均值は変化し, 段差通過後は值が上昇した. このことから，段差によって乗り心地が悪くなった ことが確認できる．また，運転者と同乗者の值を比 較すると運転者の方がリアプノフ指数の絶対值は大 きいことがわかる，これは，運転者と同乗者の個人 特性だけでなく, 運転手が橋梁（トラス橋）を通過 する際の緊張やストレスも影響していると考えられ る.

\section{d) その他の各種イベントとリアプノフ指数の関係}

試験走行（延長約 $3 \mathrm{~km}$ ) では, 前項までの加・減 速, 左折, 段差の他に, 運転条件や道路条件に起因 した走行中に生じるいくつかのイベントが記録され ており，いずれもイベントが生じる前後でリアプノ フ指数の増加を確認している.

そこで，これらのイベント（i舗装目地，(ii)舗装 段差（3cm），(iii)シーリング補修された舗装区間 (約15m)，(iv)停車車両の追い越し，(v)上り坂 (約 $25 \mathrm{~m}) ，(\mathrm{vi})$ 下り坂（約 $20 \mathrm{~m} ）)$ について，イベ ントごとの乗り心地に与える影響の程度を把握する ため, リアプノフ指数の絶対值ではなく, イベント 前後のリアプノフ指数の差を比較した. 図-10にイ ベント後のリアプノフ指数からイベント前のリアプ ノフ指数を差し引いた值（測定3回の平均值）を示 す.

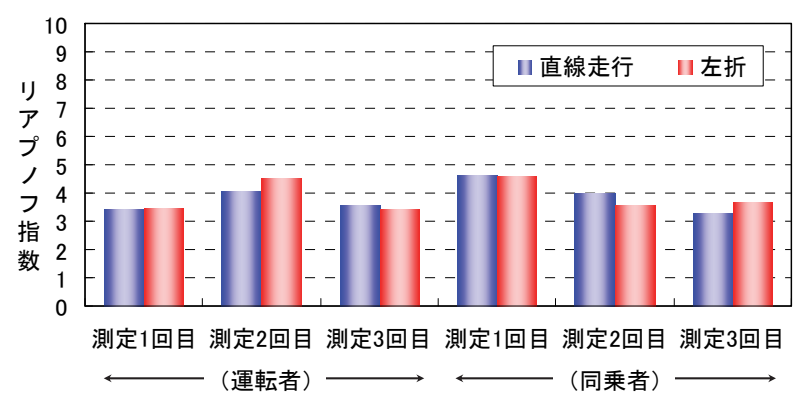

図-7 左折とリアプノフ指数の関係

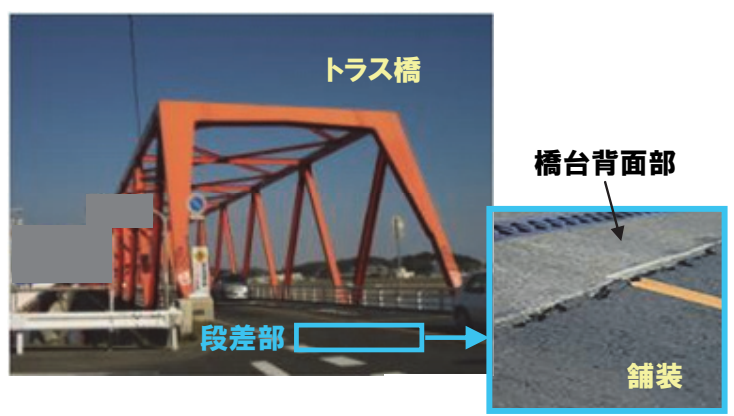

図-8 舗装と橋台背面部との段差

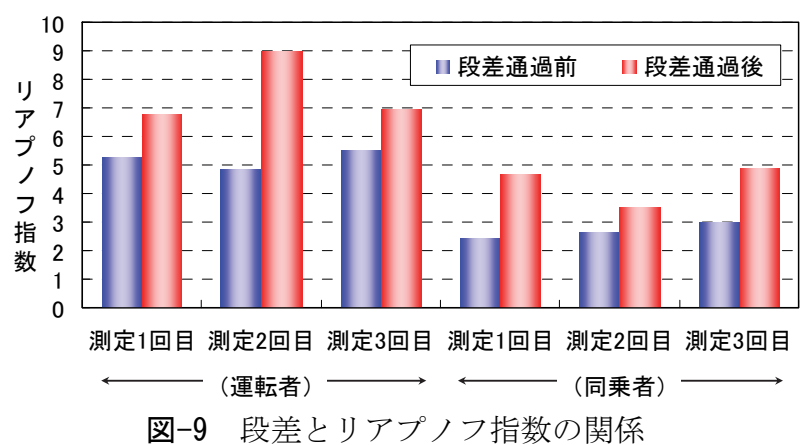

リアプノフ指数の平均値の差

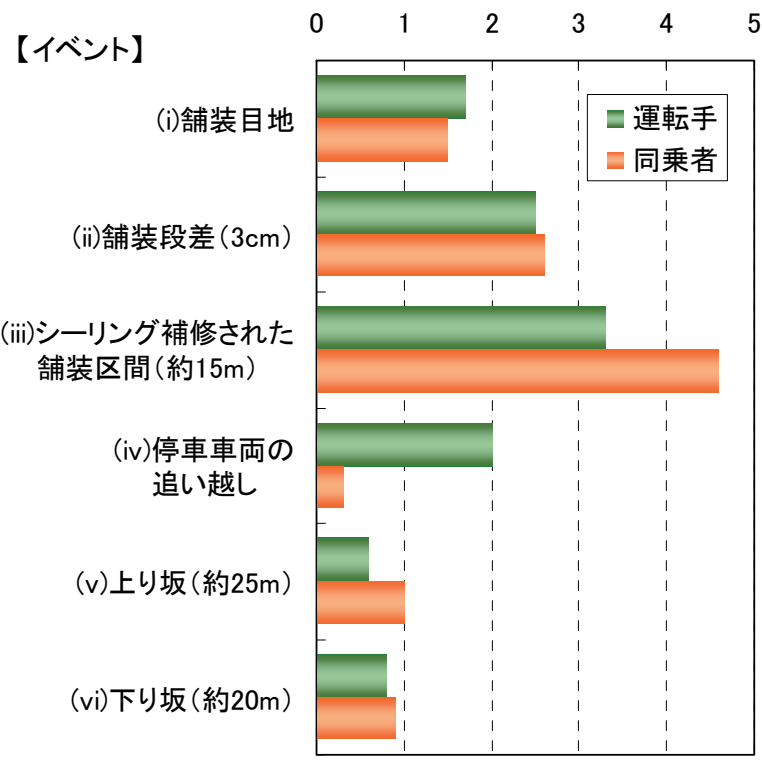

図-10 各イベント前後のリアプノフ指数の差 


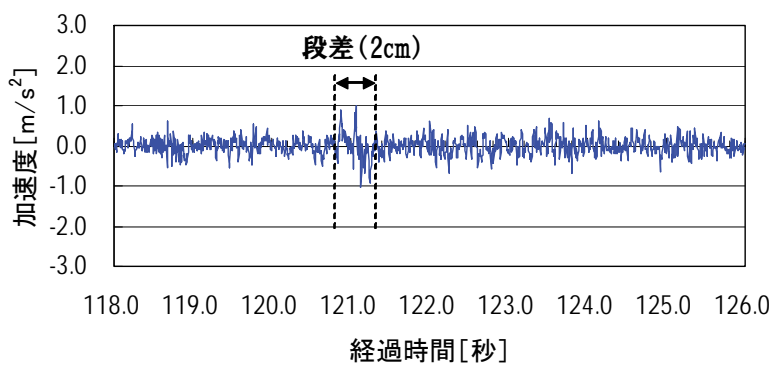

(a) 鉛直方向加速度

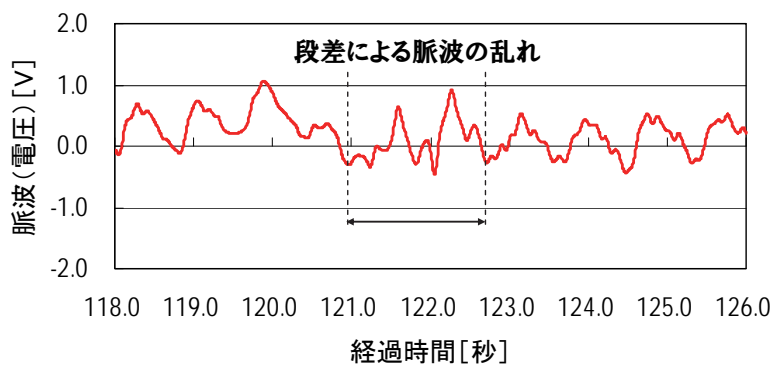

(b) 脈波

図-11 単独段差を通過したときの加速度と脈波

図-10より, イベント前後のリアプノフ指数の差 が最も大きかったものは「(iii)シーリング補修され た舗装区間」であった。路面ひび割れの応急的な補 修として用いられたシーリング剂によって路面の不 陸が延長約 $15 \mathrm{~m}$ に渡って続いている区間であり，特 に同乗者が乗り心地を不快に感じていることがわか る。また，(i)〜 (iii)までのイベントは主に路面不陸 の程度が異なるものと捉えることができ，不陸程度 の小さな舗装目地よりも段差に対して乗り心地が悪 いと感じている.さらに段差の高低差は少ないが， 不陸延長の長いシーリング補修された区間は，より 乗り心地が悪いと感じている。このように被験者の 脈波を利用寸ることで，様々なレベルの舗装路面の 不陸に伴う乗り心地を評価できる可能性が確認でき る.

また，舗装路面の不陸以外のイベントでもリアプ ノフ指数の変化が現れた。「(iv)停車車両の追い越 し」では，運転手のリアプノフ指数について差が生 じ，同乗者は大きな変化はなかった。これは運転手 が停車車両を追い越寸際の緊張感がリアプノフ指数 に反映されたものと思われ，同乗者につてはアイマ スクや耳栓の効果でほとんど変化は現れなかった。 なお，(v)上り坂や(vi)下り坂を走行することでもリ アプノフ指数の変化が現れており, これらについて は同乗者の方がやや大きな影響を受ける結果となっ たが, 路面状況や運転環境などによるイベント前後 のリアプノフ指数の差よりも大きくないことが確認 できた。

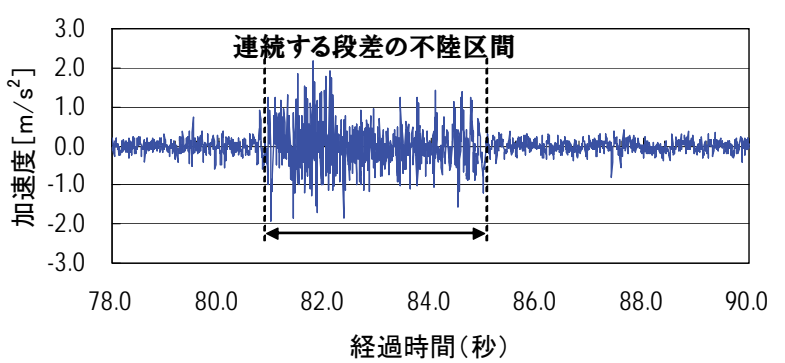

(a) 鉛直方向加速度

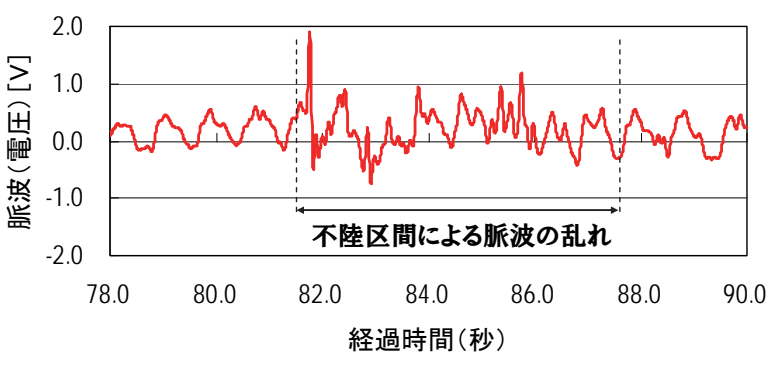

(b) 脈波

図-12 連続した段差を通過したときの加速度と脈波

\section{(3) 車両の振動と脈波の乱れに関する検討}

前項までの検討において，様々なタイプの路面不 陸が，道路の乗り心地に影響を与えることを確認し た。 そこで, 不陸延長の短い単独段差と不陸延長の 長い連続した段差の2タイプのイベントについて, それぞれのイベントから車両が受ける振動を加速度 計で計測するとともに，脈波を同時計測し，被験者 が受ける鉛直方向の振動と脈波の乱れの関係の特徵 を定性的に把握することとした，なお，ここでの被 験者は同乗者のみとした。これは，運転手が舗装の 段差や不陸の影響と同時に運転上のストレスも受け てしまうと考えたためであり，同乗者の場合はそれ らの影響を極力抑えることができると判断したため である。

本計測で用いた加速度計は（株）東京測器研究所 製のARF-20Aであり，右後部ドア（同乗者の座席付 近）に取り付け，鉛直方向の振動加速度を測定した。 また, 試験走行区間の中の約 $2 \mathrm{~cm}$ の舗装段差と前節 d)項で考察した「(iii)シーリング補修された舗装区 間」の比較を行った。前者を「不陸延長の短い単独 段差」の一例とし, 後者を「不陸延長の長い連続し た段差」の一例とした．測定は各箇所を通過する前 後の脈波と振動加速度を3回計測し, 生体脈波と車 両が受ける鉛直方向の振動加速度を比較した。計測 したときの車両の速度は法定速度の $60 \mathrm{~km} / \mathrm{h}$ から 50km/hまでの間であり, できるだけ一定速度での走 行を試みた。その他の測定条件は4章で述べたとお りである。 
まず，「不陸延長の短い単独段差」として約 $2 \mathrm{~cm}$ 段差を通過したときの結果を図-11に示寸。（a）図は 測定された鉛直方向加速度，(b) 図は被験者の脈波 である，両図を比較すると鉛直加速度によって段差 を捉えていることがわかる，また，(b)図の「段差 による脈波の乱れ」区間とその前後の区間のリアプ ノフ指数をそれぞれ計算すると，「段差による脈波 の乱れ」区間が6.15，区間前後が4.21と3.98であり， この時に脈波が乱れていることが確認できる。また， 脈波は段差通過後も乱れており, 安定した波形に戻 るまで約1秒かかっていることもわかる。このこと から1回の段差に脈波が反応しており，さらに乱れ た脈波が安定するまでにはある程度の時間を要する ことがわかる.

次に,「不陸延長の長い連続した段差」であるシ ーリング補修された舗装区間（約15m）を通過した ときの結果を図-12に示す．同様に (a) 図は測定され た鉛直方向加速度, (b) 図は被験者の脈波である。 両図を比較すると, 鉛直加速度によって段差を連続 的に捉えていることがわかる。また，(b)図の脈波 の乱れ区間とその前後の区間のリアプノフ指数をそ れぞれ計算すると，脈波の乱れ区間が8.06，区間前 後が3.34と5.27であり，この時に脈波が乱れている ことが確認できる。このことから不陸延長の長い連 続した段差にも脈波が反応していると考えられる. また脈波の乱れが安定するまでに要する時間は, 図-11に示される1回の段差の場合よりも連続した段 差の方が長い時間を要していた。これは連続的に起 こる段差により被験者のストレスが溜まり，乗り心 地の悪さを強く感じていたのではないかと考えられ る.

測定はどちらのタイプの段差についても3回実施 し，すべてにおいて同様の結果が得られた．このこ とにより，脈波は路面情報による直接的な影響ばか りではなく, 被験者の乗り心地として, 段差や不陸 通過後の余韻まで捉えていると考えられ, 脈波は加 速度分析だけからでは得られない人間の感覚的な乗 り心地を含む有用な評価指標になり得る。

\section{6. 生体脈波による複数道路の乗り心地の区別化}

本研究では，任意に設定した複数の道路区間を対 象に車両走行実験を行い, 道路ごとの乗り心地評価 值を算出し，生体脈波を用いた乗り心地の区別化の 可能性について検討した。ここで，道路ごとの「乗 り心地評価值」とは, 各被験者の生体脈波加計算 されるリアプノフ指数のことであり, 複数の被験者
から求めたリアプノフ指数をその道路の「乗り心地 評価値」とする場合は平均值を利用する。

\section{(1) 対象道路と試験方法}

本研究では, 表-1に示すように対象道路として, 有料道路（延長約 $2 \mathrm{~km}$ ) ，一般国道（延長約 $1 \mathrm{~km})$, 県道（延長約 $1 \mathrm{~km}$ ), 市町村道（延長約 $1 \mathrm{~km}$ ) の4道 路を設定した。各道路の法定速度, 車線数, 路面整 備状況および概況は表-1に示寸とおりである. 有料 道路の道路Aの整備状況はよく, 路面は平坦で走行 しやすい. 一般国道の道路Bの整備状況は比較的良 いが，一部にわだち掘れが見られる。県道の道路C の整備状況は比較的良いが，時折段差による強い振 動を受ける. そして, 市町村道の道路Dはわだち掘 れ路面が比較的多いが，目立った段差はない。

走行試験およびデータ解析は4章で述べた方法に 基づき実施した。ただし，被験者は同乗者（右後部 座席）のみとし，5名の20歳代男性（すべて1年以上 の運転経験あり）の耳架脈波を測定した。 そして, 1名の被験者が4つの各道路（道路A〜D）を1セット として日を変えて3回の走行試験を実施した。つま り，1名の被験者に対して走行試験は12回実施され， 被験者 5 人分で合計 60 セットの脈波データをサンプ リングした。なお，1セット中の各道路の走行試験 は5分の休喤を入れて連続して実施した。

データ解析においては, 走行試験中の車両走行速 度と前章で検討した各種イベント（加減速, 信号停 止，段差や不陸など）を時刻歴データとして記録し ておき, 一定速度（法定速度か, それより約 $10 \mathrm{~km} / \mathrm{h}$ 遅い速度までを可とした）で走行中の被験者の脈波 データのみを切り出して解析し, 車両走行中のリア プノフ指数 (平均值) を求めた。

\section{(2) 走行試験の結果および考察}

走行試験によって得られた5名の被験者の脈波デ 一タからリアプノフ指数を計算 (解析值) するとと もに, 各道路ごとの測定3回分の解析值の平均を求 めた。結果を表-2に示寸。また, 図-13〜17では被 験者ごとに $\mathrm{A} \sim \mathrm{D}$ の各道路の乗り心地評価值をグラ フ化した.

被験者P1の走行試験結果（図-13）をみると, 測 定1回目から3回目まで道路ごとの乗り心地評価值は 同様の傾向を示しており, 道路路面の整備状況がよ い有料道路が最も小さなリアプノフ指数となり, 片 側1車線の県道（道路C）は段差を有することで最も 大きなリアプノフ指数となっている. 道路B（一般 国道）と道路C（市町村道）の乗り心地評価值は測 定回によってばらつきが見られるが，ほぼ同等のリ 
表-1 乗り心地の比較対象とした各道路の特徵

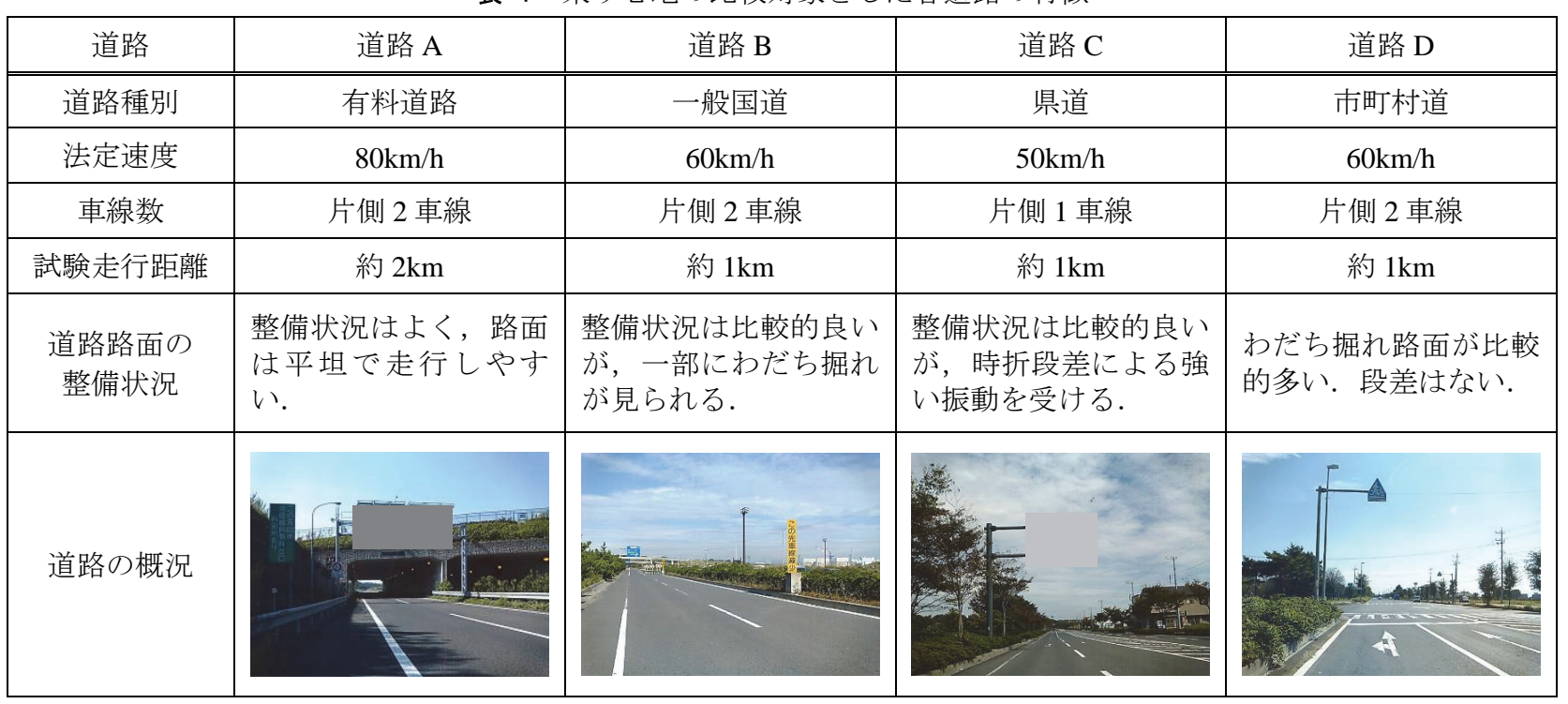

表-2 複数道路の走行試験結果（各道路のリアプノフ指数の解析值と平均值）

\begin{tabular}{|c|c|c|c|c|c|c|c|c|c|}
\hline \multirow{2}{*}{ 被験者 } & \multirow{2}{*}{$\begin{array}{l}\text { 測定 } \\
\text { 回数 }\end{array}$} & \multicolumn{2}{|c|}{ 道路A } & \multicolumn{2}{|c|}{ 道路B } & \multicolumn{2}{|c|}{ 道路C } & \multicolumn{2}{|c|}{ 道路D } \\
\hline & & 解析値 & 平均 & 解析值 & 平均 & 解析值 & 平均 & 解析值 & 平均 \\
\hline \multirow{3}{*}{ 被験者P1 } & 1回目 & 1.50 & \multirow{3}{*}{1.55} & 2.59 & \multirow{3}{*}{2.16} & 3.06 & \multirow{3}{*}{2.88} & 1.80 & \multirow{3}{*}{1.85} \\
\hline & 2回目 & 1.56 & & 2.00 & & 2.97 & & 1.98 & \\
\hline & 3回目 & 1.60 & & 1.89 & & 2.60 & & 1.77 & \\
\hline \multirow{3}{*}{ 被験者P2 } & 1回目 & 3.98 & \multirow{3}{*}{3.40} & 5.91 & \multirow{3}{*}{4.64} & 6.62 & \multirow{3}{*}{5.59} & 5.48 & \multirow{3}{*}{4.70} \\
\hline & 2回目 & 3.19 & & 3.87 & & 4.60 & & 4.00 & \\
\hline & 3回目 & 3.04 & & 4.13 & & 5.54 & & 4.63 & \\
\hline \multirow{3}{*}{ 被験者P3 } & 1回目 & 3.32 & \multirow{3}{*}{4.79} & 3.90 & \multirow{3}{*}{5.80} & 4.68 & \multirow{3}{*}{6.74} & 3.05 & \multirow{3}{*}{5.10} \\
\hline & 2回目 & 6.65 & & 6.90 & & 8.16 & & 6.85 & \\
\hline & 3回目 & 4.39 & & 6.60 & & 7.39 & & 5.40 & \\
\hline \multirow{3}{*}{ 被験者P4 } & 1回目 & 2.00 & \multirow{3}{*}{1.90} & 3.59 & \multirow{3}{*}{2.60} & 3.96 & \multirow{3}{*}{3.36} & 3.22 & \multirow{3}{*}{2.69} \\
\hline & 2回目 & 1.36 & & 2.15 & & 2.56 & & 2.26 & \\
\hline & 3回目 & 2.33 & & 2.06 & & 3.56 & & 2.59 & \\
\hline \multirow{3}{*}{ 被験者P5 } & 1回目 & 4.29 & \multirow{3}{*}{3.52} & 5.48 & \multirow{3}{*}{4.52} & 6.22 & \multirow{3}{*}{5.51} & 5.90 & \multirow{3}{*}{4.52} \\
\hline & 2回目 & 3.60 & & 4.09 & & 4.80 & & 3.56 & \\
\hline & 3回目 & 2.66 & & 3.98 & & 5.50 & & 4.09 & \\
\hline
\end{tabular}

アプノフ指数となっていることから，被験者にとっ て乗り心地は同等であり，乗り心地の善し悪しを区 別しにくい道路であると考えられる.

被験者P2（図-14）～被験者P5（図-17）において も同様に, 道路Aを乗り心地のよい道路, 道路Cを 乗り心地の悪い道路とする傾向が強い. リアプノフ 指数の值は被験者の個人差や測定回の生体条件の違 いによって異なる結果となっているが, 各道路の乗 り心地評価值の相対的な関係はほぼ保たれており, 道路の区別化が可能なことが分かる。

なお，今回の走行試験では道路ごとの法定速度が 異なることから，乗り心地に影響を与える要因の一 つである段差や不陸などを通過する速度の影響で, 被験者の受ける乗り心地が変化すると考えられる. よって, 本結果は各道路をほぼ法定速度で走行する
場合の各道路の乗り心地の相対評価である.

以上の結果を踏まえ, 各道路の相対的な乗り心地 を確認するため, 表-2に示した被験者ごとの各道路 に対する乗り心地評価值の平均值をグラフ化した. ただし，被験者ごとのリアプノフ指数には違いがあ るため, 最も乗り心地の良いと判断された道路 $\mathrm{A}$

（有料道路）を基準に, 他の道路の乗り心地評価值 を換算した。図-18に道路Aの乗り心地評価值を 1 と した場合のその他の道路の乗り心地評価值を示す. 図より, 乗り心地のよい道路は道路A, 乗り心地の 悪い道路は道路Cとなっていること, 道路 $\mathrm{B}$ と道路 $\mathrm{D}$ の乗り心地はほぼ同等であり, 乗り心地の善し悪し を区別しにくい道路であることが再確認でき, 道路 の区別化が可能なことが分かる。 


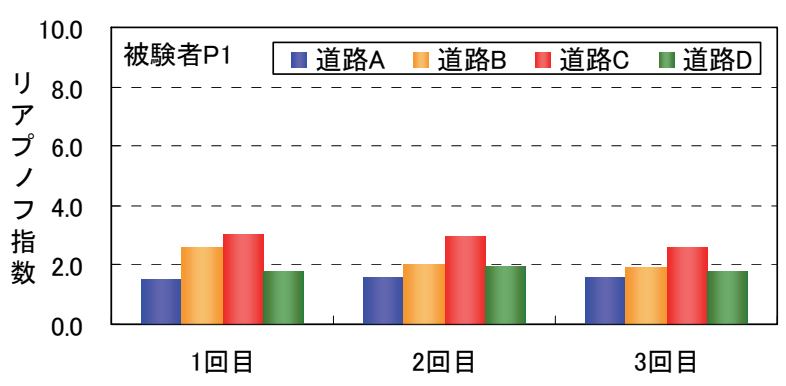

図-13 複数道路の乗り心地評価值の比較（被験者 P1）

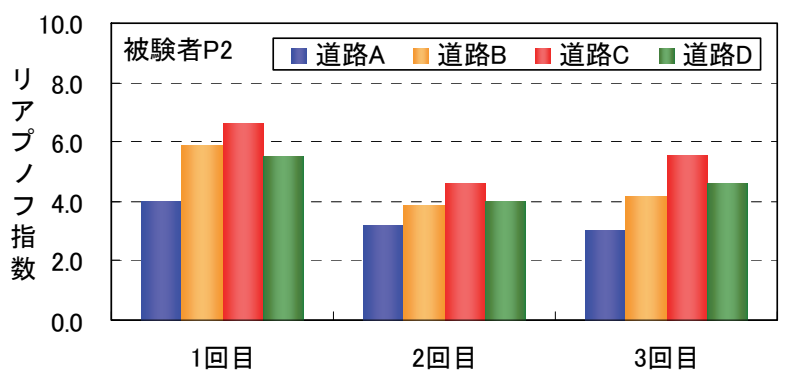

図-14 複数道路の乗り心地評価值の比較（被験者 $\mathrm{P} 2$ ）

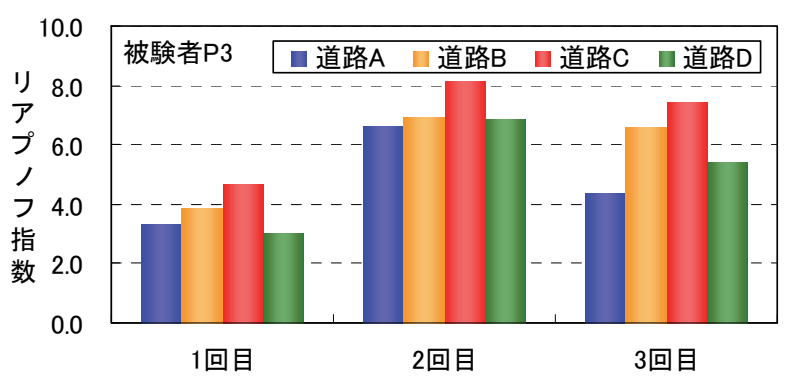

図-15＼cjkstart複数道路の乗り心地評価值の比較（被験者 P3）

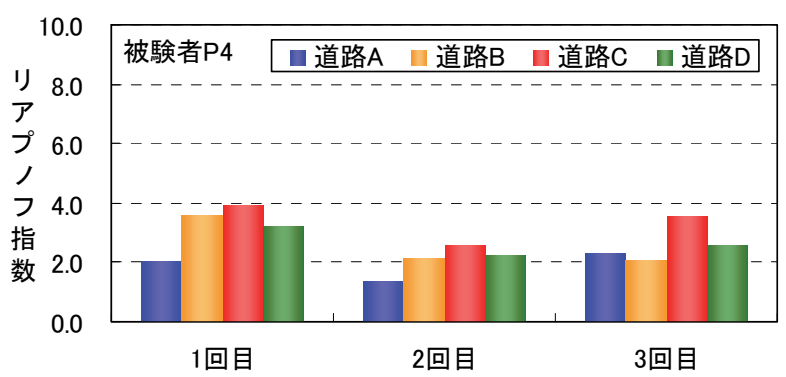

図-16 複数道路の乗り心地評価值の比較（被験者 P4）

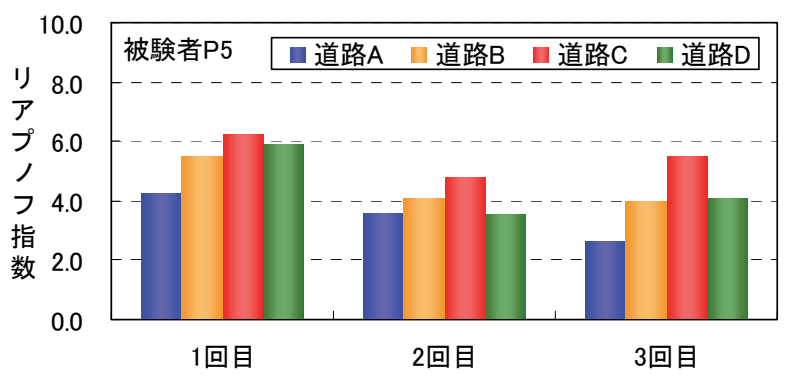

図-17 複数道路の乗り心地評価值の比較（被験者 P5）

以上の分析結果より，被験者の個人差はあるもの の, 脈波のリアプノフ指数を道路の乗り心地と定義

\section{道路Aを1とした場合の各道路の乗り心地評価値}

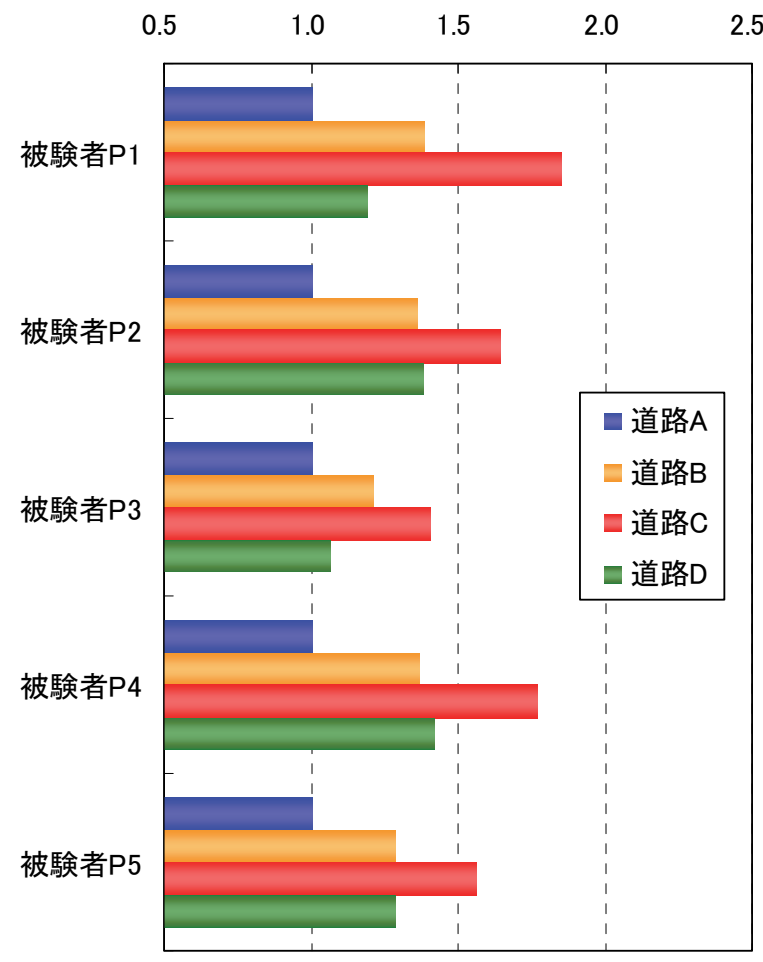

図-18 道路 $\mathrm{A}$ の乗り心地評価值を 1 とした場合の 各道路の乗り心地評価值の比較（全被験者）

し，道路ごとの乗り心地評価値を着目道路に対して 基準化することで，生体脈波を用いた道路の乗り心 地の区別化が可能となる。そして，生体脈波による 乗り心地評価は，単に路面の物理的な特性や車両が 受ける振動だけでなく, 道路利用者が車両走行中に 受ける道路の乗り心地を総合的に評価できる指標で あると考えられる。

しかしながら, 本研究の分析結果は, 走行車両の 速度や道路線形, 被験者の個人差などに起因する乗 り心地の違いを包括したものであると見るべきであ る.よって, 今後はデータのサンプリング数を増や すとともに，属性の異なる多様な被験者での評価に ついても拡大検討することが必要であると思われる.

\section{7. 結論}

本研究では, 道路利用者の乗り心地を定量化した 走行性指標を提案するため, 車両走行中の運転者お よび同乗者の生体脈波をセンシングし，人間の感覚 的な観点からの道路の乗り心地を評価する手法を提 案するとともに, 舗装マネジメントにおける乗り心 地指標の利用方法に関する検討を行った。結論を以 下に示す. 
1）車両走行試験によって被験者（運転手および同 乗者）の生体脈波と路面評価指標のMCI と平坦 性とを比較した結果，運転手および同乗者の生 体脈波から計算されるリアプノフ指数は，必ず しも同じ傾向を示しておらず，さらにリアプノ フ指数とMCIおよび平坦性の間に顕著な相関は 見られなかった。

2) 車両走行試験によって運転条件や道路条件に起 因した走行中に生じる各種イベントとリアプノ フ指数の関係を分析した結果, 車両の停止や加 減速は乗り心地にある程度の影響を与えるが, 左折の影響についてはそれほど無いことが確認 できた。また，舗装と橋台背面部との段差の影 響については，被験者が段差によって乗り心地 が悪いと感じていること，運転者のリアプノフ 指数が橋梁を通過する緊張やストレスによって 大きくなることが確認された.

3) 路面ひび割れの応急的な補修として用いられた シーリング剂によって路面の不陸が長区間に渡 って続く道路では，特に同乗者が乗り心地を不 快に感じ，段差や舗装目地よりも乗り心地が悪 いと評価している。このことから，同乗者の脈 波を利用することで，様々なレベルの舗装路面 の不陸に伴う乗り心地を評価できる可能性があ る.

4) 不陸延長の短い単独の段差と不陸延長の長い連 続した段差の2タイプについて，鉛直方向の車 両振動と生体脈波の乱れを定性的に把握したと ころ，段差によって脈波の乱れが生じるととも に，乱れた脈波が安定するまでにはある程度の 時間を要することがわかった。また，単独の段 差の場合よりも連続した段差の方が乱れは大き く，連続的に起こる段差により被験者の不快感 が溜まり，乗り心地の悪さを強く感じたと考え られる。

5）任意に設定した複数の道路区間を対象に，道路 ごとの乗り心地評価值によって道路の区別化の 可能性について検討した結果，乗り心地評価值 は被験者の個人差や測定回の生体条件の違いに よって異なるが, 各道路の乗り心地評価值の相 対関係は保たれており, 道路の区別化が可能で ある・

6) 道路ごとの乗り心地評価值を着目道路に対して 基準化することで，道路の乗り心地の区別化が より鮮明化できる。このことから，道路利用者 の生体脈波を評価する方法が，道路の乗り心地 を区別化する新たな評価方法として有効である と考えられる。
7) 今後, 性別や年齢構成の異なる道路利用者を被 験者として選出し, 本研究と同様の検討を行う ことによって，生体脈波から求められる道路の 乗り心地評価值の汎用性が高まると思われる.

そして，道路の維持管理を行う際に，これまで の管理指標に加えて, 道路利用者の生体情報に よる乗り心地の観点からの評価を考慮すること で，舗装の維持修繥を中心とした道路整備の優 先順位の決定や整備効果の検証に利用できると 考えられる.

謝辞：本研究の一部は, 文部科学省 科学研究費補 助金 基盤研究(C)（課題番号：18560462, 課題番 号：22560471）の援助を受けた。ここに，記して謝 意を表す.

\section{参考文献}

1) 土木学会建設マネジメント委員会アセットマネジメン 卜研究小委員会 : アセットマネジメント導入への挑戦 一新たな社会資本マネジメントシステムの構築に向け て一, 平成 14 年度報告書, 2003 .

2) 石田 樹, 岳本秀人, 川村 彰, 白川龍生 : ドライビ ングシミュレータによる舗装路面の乗り心地と走行安 心感の評価, 北海道開発土木研究所月報, No.630, pp.37-45, 2005.

3) 大野滋也, 佐藤正和, 鈴木一隆 : 「乗り心地」に着目 した路面管理指標に関する研究, JH 試験研究所道路 研究部舗装研究, EXTEC, 61 号, Vol.16, No.1, pp.37-40, 2002.

4) 諸橋淳一, 高木 久, 河合雅己：路面性状測定車によ る乗り心地評価の精度検証, 財団法人日本測量調査技 術協会, APA, No.82-16, pp.106-112, 2002.

5) 熊田一彦, 大野滋也, 佐藤正和 : 高速道路の構造 - 交 通諸元と IRI の関係について, 土木学会舗装工学論文 集, 第 7 集, pp.10-1〜2, 2002.

6) 遠藤 桂 : 感性に基づいた舗装の評価と舗装マネジメ ントへの適用, 中央大学理工学研究科土木工学専攻博 士論文, 2004.

7) Endo, K., Himeno, K., Kawamura, A., Hachiya, Y. and Matsui, K. : Evaluation of Longitudinal Runway Profile and Ride Quality Using Wavelet Analysis and Brain Waves, TRB 82nd Annual Meeting, Washington D.C., 2003.

8) 光井輝彰, 千原健司, 稲葉昭夫, 永田可彦, 福田 修：人にやさしいモニタロボットの研究，岐阜県生産 情報技術研究所所報，第 4 報，pp.27-30， 2003.

9) 光井輝彰, 横山貴宏, 永田可彦, 福田 修: 人にやさ しいモニタロボットの研究（第 2 報），岐阜県生産情 報技術研究所所報, 第 5 報, pp.27-32, 2004.

10) 大橋義彦 : 舗装の維持管理システム, 道路, pp. 49-53, 1997.

11) 苗 鉄軍, 清水俊行, 下山 修: 生体のカオス性によ るドライバーの精神負荷状態評価, 自動車技術会春季 学術講演会, 学術講演会前刷集 No.18-03, 2003.

12) 清水俊行, 苗 鉄軍, 下山 修: 指尖脈波のカオス分 析を用いたドライバの心身状態の定量化, ヒューマニ 
ンターフェース学会研究報告集, Vol.6, No.1, pp.9799, 2004.

13) 株式会社 CCI カオス複雑系事業部「カオスについ て」: http://chaos.cci-web.co.jp/chaos.html

14) 合原一幸編, 池口徹, 山田泰司, 小室元政著 : カオス 時系列解析の基礎と応用, 産業図書, 2000 .
15) (社)人間生活工学研究センター : ストレス計測技術の 安全対策への適用可能性に関寸る調查研究報告書, 2004.

(2010. 9.8 受付)

\section{BASIC STUDY ON EVALUATION OF ROAD RIDING COMFORT BY USING BIOLOGICAL PULSE WAVE}

\section{Takao HARADA and Koichi YOKOYAMA}

In this study, the methodology to evaluate a road riding comfort was proposed by using biological pulse wave. The road riding comfort was defined by Lyapunov exponent calculated from biological pulse wave of driver and passenger during vehicles running. Through some experiment, it was found that the biological pulse wave was effective as the way of adopting human sensuous evaluation in order to estimate influence of the road riding comfort. And how to use the road riding comfort index was examined for road asset management. It could confirm that the riding comfort of every road could be distinguished by using biological pulse wave relatively. 